\title{
Kamu-Özel İşbirliği (Yap-Kirala-Devret) Modeli ve Şehir Hastanelerinin Sağlık Hizmetlerindeki Değişim ve Dönüşüm Üzerine Etkileri
}

Kamu-Özel İşbirliği (Yap-Kirala-Devret) Modeli ve Şehir Hastanelerinin Sağlık Hizmetlerindeki Değişim ve Dönüşüm Üzerine Etkileri

Öz

Bu çalışmada, kamu-özel işbirliğinin (KÖi) bir alt modeli olan yap-kirala-devret (YKD) modeli çeşitli açılardan analiz edilmekte ve YKD modeliyle yapılan ve işletilen şehir hastanelerinin sağlık hizmetlerinin değişimi ve dönüşümü üzerine etkileri incelenmektedir. $\mathrm{Bu}$ bağlamda, çalışma iki bölümden oluşmaktadır. Birinci bölümde KÖi ve YKD'nin kavramsal çerçevesi ele alınmakta ve sağlık hizmetlerinde kullanılan KÖi modelleri incelenmektedir. İkinci bölümde, sağıı sektöründe YKD modelinin uygulanmasında etkili olan faktörler ele alınmaktadır. Bu faktörler, sağlık tesislerinin fiziksel altyapısının yetersizliği, sağlık harcamalarının bütçe üzerinde oluşturduğu baskı, özel sektörün tecrübesinden yararlanma isteği ve düşük kalite standartları şeklinde sıralanmaktadır. Daha sonra, bu faktörler çerçevesinde, şehir hastanelerinin sağlık hizmetlerinin değişimi ve dönüşümüne etkileri analiz edilmektedir.

Anahtar Kelimeler: Kamu-Özel İşbirliği, Yap-KiralaDevret, Şehir Hastaneleri, Sağlık Hizmetleri
Public-Private Partnership (Build-Lease-Transfer) Model and The Effects of City Hospitals on The Change and Transformation of Health Services

Abstract

The build-lease-transfer (BLT) model, which is categorized under the public-private partnership (PPP) model, has been analyzed from various perspectives and the effects of city hospitals, which are built and operated as a part of BLT model, on the change and transformation of health services are examined in this study. In this context, the study consists of two chapters. While the conceptual framework of PPP and BLT is discussed and PPP models used in health services are explained in the first chapter, the factors affecting the implementation of BLT model in the health sector are discussed in the second chapter. These factors are listed as follows; the inadequacy of the physical capacity of health facilities, pressure on the budget caused by health expenditures, the desire to benefit from the experience of the private sector and low quality standards. Lastly, the effects of city hospitals on the change and transformation of health services are analyzed within the framework of these factors

Keywords: Public-Private Partnership, Built-LeaseTransfer, City Hospitals, Health Services

\section{Giriş}

Bazı kamu hizmetlerinin özel sektöre gördürülmesi Roma İmparatorluğu'na kadar geçmişe dayandırımakla birlikte Türkiye'de bu süreç Osmanlı döneminde 1910 yılında kabul edilen Menafii Umumiyeye Müteallik İmtiyazat Hakkında Kanun'la başlamıştır. Bu kanundan sonra cumhuriyet döneminde özel sektörün elindeki sermaye yetersizliği, Keynezyen ekonomik model ve refah devletinin genel kabulleri, uluslararası konjonktürden kaynaklanan istikrarsızlıklar ve savaşlar gibi sebeplerden dolayı özel sektör kamu hizmetlerinde çok fazla rol alamamıştır. Ancak, 1980'lerden sonra Neoliberal akımın etkisiyle devletin ekonomik hayattan mümkün olduğunca çekilmesi, kamu yatırımlarında özel sektör sermayesinden ve işletme tekniğinden daha çok faydalanılması anlayışı kapsamında başta özelleştirme ve imtiyaz uygulamaları olmak üzere çeşitli yöntemlere sıklıkla başvurulmuştur.

\footnotetext{
${ }^{1}$ Dr., Öğr. Üyesi, Kütahya Dumlupınar Üniversitesi, Gediz Meslek Yüksekokulu, uysal20@hotmail.com, Yazar ORCID bilgisi: https://orcid.org/0000-0003-3872-3119
} 
Bu yöntemlerden biri olan KÖi, özellikle 1990'lardan itibaren Birleşik Krallık'ta uygulanmaya başlanmış ve gün geçtikçe etkinliği ve kapsamı arttırılmış bir modeldir. Ülkeler ekonomik ve siyasi yapılarını ve KÖi uygulanacak sektörü göz önünde bulundurarak KÖi'nin çeşitli alt modellerini geliştirmişler ve bazı alt modelleri diğerlerine oranla daha çok kullanırken bazılarını hiç kullanmamışlar veya daha az kullanmışlardır. Bu süreçte, KÖínin çeşitli alt modelleriyle en çok uygulandığı sektörlerin biri olan sağlık sektöründe altyapı tesislerinin inşa edilmesinden ilaç üretimine, önleyici ve koruyucu sağlık hizmetlerinin sunumundan sağlık destek hizmetlerinin yürütülmesine kadar geniş bir yelpazede KÖi modelinin uygulandığı görülmektedir.

Türkiye'de sağlık sektöründe KÖi uygulamalarında süreç 2005 yılında kabul edilen 5396 sayılı Sağlık Hizmetleri Temel Kanununa Bir Ek Madde Eklenmesi Hakkında Kanun ile başlamış, 2013 yılında 6428 Sayılı Sağlık Bakanlığınca Kamu Özel İşbirliği Modeli ile Tesis Yaptırıması, Yenilenmesi ve Hizmet Alınması ile Bazı Kanun Hükmünde Kararnamelerde Değişiklik Yapılması Hakkında Kanun'un kabul edilmesiyle devam etmiştir. Söz konusu kanundaki düzenlenen model genel olarak, sağlık bakanlığından alacağı bedeller karşılığında özel sektör girişimcilerinin sağlık tesisini inşa etmesi, tesisi bakanlığa tahsis etmesi, sağlık hizmetlerinin kamu personellerince, destek hizmetlerin ise özel sektör girişimcileri tarafından sunulması ve sözleşme süresinin sonunda tesisin bakanlığa devrinin yapılması esaslarına dayanmaktadır. YKD olarak adlandırılan ve KÖi'nin bir alt modeli olan bu model ile Türkiye'de hem sağlık sektörü altyapısında hem sağlık hizmetlerinin kapsamı, sunuş şekli ve kalitesinde çok önemli değişimlerin ve dönüşümlerin gerçekleştirilmesi planlanmıştır. Türkiye'de 2003 yılından itibaren sağlıkta dönüşüm programı kapsamında gerçekleştirilen bu modelle sekizi (8) hizmete alınmış olmak üzere, çeşitli aşamalarda 21 şehir hastanesi projesi yürütülmektedir.

$\mathrm{Bu}$ araştırma iki (2) bölümden oluşmaktadır. Birinci bölümde YKD modelinin kavramsal çerçevesi ile modelin yapısı ve temel özellikleri incelenmektedir. İkinci bölümde ise, Türkiye'de YKD modelinin uygulanmasına etki eden faktörler ve YKD modeli ile inşa edilen ve işletilen şehir hastanelerinin sağlık hizmetlerinin değişimi ve dönüşümüne etkileri analiz edilmektedir.

\section{Kamu Özel İşbirliği (KÖi) ve Yap-Kirala-Devret (YKD)}

\subsection{Kavramsal Çerçeve}

KÖi, bir malın veya hizmetin topluma sunulması amacıyla kamu ile özel sektör girişimcileri arasında yapılan ve özel sektöre yeterli oranda riskin devredildiği bir sözleşme temelinde kurulan işbirliğidir (Joyner, 2007: 207). KÖi, kamu idareleri ile özel sektör girişimcilerinin risk ve kazanç paylaşımını esas alan ve genellikle uzun vadeli bir sözleşmeye dayanarak bir kamu hizmetini beraber yürüttükleri kamu hizmeti yürütme, satın alma ve finansman modeli olarak da tanımlanabilir. Bu tanımlar KÖi'nin oldukça kapsamlı bir kavram olduğunu ve geniş bir uygulama alanının bulunduğunu ortaya koymaktadır.

KÖI, kamu hizmetlerinin tamamen kamu kaynakları ve imkanları ile yürütüldüğü emanet yöntemi ile bir kamu tesisinin ve/veya hizmetinin özel sektöre tamamen devredilmesi olarak tanımlanabilen özelleştirme yöntemi arasında yer almaktadır. Hem özelleştirme hem KÖi kamu hizmetlerine özel sektörün daha çok müdahil olması ve hizmetlerde etkinliğin sağlanması amacıyla başvurulan yöntemler olmalarına rağmen, özelleştirmede kamu sektörü kamu hizmeti üzerindeki kontrolü kaybederken, KÖi'de kamu sektörü kamu hizmetleri üzerindeki kontrolü kaybetmemekte, özel sektör girişimcisi ile işbirliği içerisinde faaliyet yürütmektedir. 
Günümüzde dünya üzerinde sosyoekonomik bakımdan birbirlerinden oldukça farklı birçok ülkede ulaşım, eğitim, sağlık, enerji, su/sulama, kentsel dönüşüm, toplu konut, tarım gibi sektörlerde yaygın olarak kullanılan KÖi modeli, çeşitli faktörlere bağlı olarak birbirinden farklılık arz eden yap-işlet-devret (YID), yap-işlet (Yi), yap-kirala-devret (YKD), işletme hakkı devri ve gelir ortaklığı gibi birçok alt modelle uygulanan bir çatı kavramdır. KÖi'nin söz konusu alt modellerinin ortaya çıkmasında KÖi projelerinde finansman temin yöntemleri, kamu ve özel sektörün üstlendikleri görev ve sorumluluklar, risk paylaşımı, özel sektör girişimcilerine ödenecek bedeller ve bu bedellerin nasıl karşılanacağı gibi konularda farklı uygulamalar geliştirilmesi rol oynamıştır. Ayrıca, birbirlerinden oldukça farklı doğaya sahip sektörlerde KÖi projelerinin uygulanması da farklı alt modellerin ortaya çıkmasında etkili olan bir faktördür.

Yaygın bir kullanım alnına sahip olan KÖi'nin alt modellerinden biri olan YKD, özellikle sağlık, eğitim, konut ve hükümet binalarının inşası gibi sosyal alanlarda başvurulan bir modeldir. YKD, kendisine bir arazi tahsisi yapılan (bazı uygulamalarda arazinin özel sektör girişimcisine ait olması da söz konusu olabilmektedir) özel sektör girişimcisinin söz konusu tesisi tasarlaması, finanse ve inşa etmesi, genellikle 25 yıl gibi uzun bir süre ile işletmesi, bakım ve onarımını yapması karşıı̆ı̆ında müşteri konumundaki kamu idaresinden bedel(ler) tahsil etmesi ve sözleşme süresinin sonunda tesisi kamu idaresine devir etmesi şeklinde uygulanan bir modeldir (Gibss, 2008: 3). YKD’yi eksik imtiyaz olarak ifade eden Karahanoğulları'na göre ise, YKD bir kamu hizmetinin yürütülmesi için gerekli olan altyapının (binanın, tesisin) yapım işinin özel sektör tarafından üstlenilmesi, kamu sektörünün müteahhidin kiracısı olarak çekirdek hizmeti yürütmesi ve hizmet parçalarının özel girişimciye yaptırılması olarak tanımlanmaktadır (Karahanoğulları, 2011: 81).

YKD modeline, Devlet Planlama Teşkilatı tarafından 2007 yılında hazırlanan ancak yasalaşamayan "Bazı Yatırım ve Hizmetlerin Kamu Kesimi ile Özel Sektör İşbirliği Modelleri Çerçevesinde Gerçekleştirilmesine iliş̧kin Kanun Tasarısı Taslağında" da yer verilmiştir. Taslakta KÖi modelleri olarak YID, Yi, işletme hakkı devri gibi modellerle birlikte YKD modeli de (taslakta "yap-kirala" olarak ifade edilmiştir) tanımlanmıştır. Buna göre, YKD "Kamu ile özel sektör arasında akdedilen bir sözleşme çerçevesinde bir yapının özel sektör tarafından finanse edilerek yapıldığı, gerekli hallerde tasarlandığı, belirli bir süre için idareye kiralandığı, kiralanan yapı üzerindeki bazı mal ve hizmet üretim birimlerinin kısmen veya tamamen yapıma tarafından işletilebildiği ve yapının mülkiyetinin kira dönemi sonunda sözleşmede düzenlenmesi durumunda kamuya geçtiği KÖi modeli" şeklinde tanımlanmıştır.

Daha kapsamlı bir tanımla YKD, bir kamu hizmetinin yürütülmesi için yapılmasına ihtiyaç duyulan tesislerin hazine arazileri üzerinde bağımsız ve sürekli nitelikte üst hakkı tesis edilmek suretiyle özel sektör girişimcileri tarafından planlanması, finansmanın sağlanması, inşa edilmesi, sözleşme süresince işletilmesi ve belirli bir bedel ve süreyle kamuya kiralanması/tahsis edilmesi şeklinde işleyen; tesiste sunulacak asıl kamu hizmetinin kamu personellerince destek hizmetlerin ise, özel sektör girişimcileri tarafında yürütülmesi esasına dayanan KÖi modeli olarak tanımlanabilir.

YKD, 03.07.2005 tarih ve 5396 Sayılı Sağlık Hizmetleri Temel Kanununa Bir Ek Madde Eklenmesi Hakkında Kanun ile ilk kez mevzuatta yer almıştır. 2005-2013 yılları arasında YKD modeli ile sağlık alanındaki yatırımlar bu kanun çerçevesinde gerçekleştirilmiştir. Bu süreçte Sağlık Bakanlığı tarafından yapılmak istenen bazı yatırımlar çeşitli eleştirilere maruz kalmış ve bazı kurum ve kuruluşlarca yargıya taşınmıştır. Eleştirilen konular arasında sağlık alanındaki KÖI'nin genel ve çerçeve bir mevzuatla düzenlenmemesi, konunun temel kanuna eklenen kısa 
bir madde ile düzenlenmeye çalışılması ve kanunda olmayan birçok maddenin yönetmelikle düzenlendiği gibi hususlar yer almıştır (Çakır, 2016 : 90). Konunun müstakil bir kanunda düzenlenmesi ise, 21.02.2013 tarihli ve 6428 Sayılı Sağıık Bakanlığınca Kamu Özel İşbirliği Modeli ile Tesis Yaptırılması, Yenilenmesi ve Hizmet Alınması ile Bazı Kanun Hükmünde Kararnamelerde Değişiklik Yapılması Hakkında Kanun'un yürürlüğe girmesiyle mümkün olmuştur.

Yukarıda belirtildiği üzere YKD KÖI'nin bir alt modelidir. Ancak, uygulamada ve literatürde YKD yerine KÖi kavramının sıklıkla kullanılması kavram kargaşasına yol açmaktadır. KÖI'nin bünyesinde birbirinden farklı uygulama yöntemleri olan çeşitli alt modeller barındıran bir çatı kavram olduğu yukarıda ifade edilmiştir. YiD veya YKD gibi bir alt modeli ifade ederken KÖi kavramını kullanmak "KÖI'nin hangi alt modeli" sorusunu akla getirdiğinden yeterince açıklayıcı olmamaktadır. Bu durum 6428 Sayılı Kanun'un genel gerekçesinde de ifade edilmiştir. 6428 Sayılı Kanun her ne kadar "Sağlık Bakanlığınca Kamu Özel İşbirliği Modeli ile Tesis Yaptırılması, Yenilenmesi ve Hizmet Alınması ile Bazı Kanun Hükmünde Kararnamelerde Değişiklik Yapılması Hakkında Kanun" olarak adlandırılmış ve başlı̆ında "Kamu-Özel İşbirliği modeli" ifadesi kullanılmış olsa da Kanun'un genel gerekçesinde "kaliteli, verimli ve etkili sağlık hizmeti sunumu için ihtiyaç duyulan tesislerin kamu özel işbirliği modellerinden birisi olan 'yap-kirala-devret finansal modeli' ile yaptırılması ve modernize edilmesi amaçlanmaktadır" ifadesi kullanıldığından aslında kanun koyucunun "Kamu-Özel İşbirliği" ibaresini kullanmaktaki amacının YKD modeli olduğu anlaşılmaktadır. Ayrıca, Başbakanlığın TBMM Başkanlığı'na yazdığı 7.12.2012 tarih ve B.02.0KKG.0.10/101-663/5230 sayılı "Sağlık Bakanlığınca Kamu Özel İşbirliği Modeli ile Tesis Yaptırılması, Yenilenmesi ve Hizmet Alınması Hakkında Kanun Tasarısı" konusundaki yazıda da tasarının amacı; "kaliteli verimli ve etkili sağlık hizmeti sunumu için ihtiyaç duyulan tesislerin kamu özel işbirliği modellerinden birisi olan yap kirala devret finansal modeli ile yaptırılması ve modernize edilmesi" olarak belirtilmiş ve yap-kirala-devret kavramı kullanılmıştır (T.C. Başbakanlık Kanunlar ve Kararlar Genel Müdürlüğü, 2012).

\subsection{Sağlık Hizmetlerinde Köi Modelleri}

KÖi'lerin hangi hizmetlere ulaşmak amacıyla kullanılacağı tercih edilen modele göre değişmekle birlikte genel olarak, bir KÖi uygulamasıyla altı hizmetten bir ya da daha fazlasına ulaşmak amaçlanabilir. Bu hizmetler projenin finansmanı, tasarımı, yapımı, bakımı, işletmesi ve dağıtımı hizmetlerinin biri veya daha fazlası olabilmektedir. Sağlık hizmetlerinde KÖI'nin uygulanması, kamu ve özel sektörün projede üstlendikleri sorumluluk ve risk oranlarına göre farklılık arz etmektedir. Özel sektör girişimcileri KÖi projelerinde başta finansman olarak, bütün sorumluluğu veya belli bazı sorumlulukları üstlenirken kamu sektörü de özel sektör girişimcilerine bazı güvenceler sağlamaktadır (Nikolic ve Maikisch, 2006: 2). Buna göre, Şekil 1'de görüldüğü gibi, sağlık hizmetlerindeki KÖi'ler sağlık altyapısını inşa etmek veya yenilemek için tercih edilen "altyapı tabanlı model", hizmet sunma kapasitesini arttırmak veya genişletmek için tercih edilen "ayrık klinik servisler modeli" ve kapsamlı bir altyapı ve hizmet sunumunu sağlamak amacıyla tercih edilen "entegre KÖi modeli" olmak üzere üç model şeklinde uygulanabilmektedir (Abuzaineh vd., 2018: 12). 
Şekil 1: Sağlık Hizmetlerinde Uygulanan KÖi Modelleri

\begin{tabular}{|c|c|c|c|}
\hline $\begin{array}{l}\text { KÖİ Model } \\
\text { Çeşitleri }\end{array}$ & Altyapı Temelli Model & Ayrık Klinik Hiz. Mod. & Enteğre KÖİ Modeli \\
\hline & 7 & 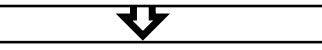 & Y \\
\hline $\begin{array}{l}\text { KÖİ Modeli } \\
\text { Bileşenleri }\end{array}$ & $\begin{array}{l}\text { Alt yap } 1+\text { Finansman }+ \\
\text { Klinik olmayan hizmetler }+ \\
\text { Klinik Destek Hizmetleri }\end{array}$ & Klinik Hizmetler & $\begin{array}{l}\text { Alt yap } 1+\text { Finansman }+ \\
\text { Klinik hizmetler + Klinik } \\
\text { destek hizmetleri + Klinik } \\
\text { olmayan hizmetler }\end{array}$ \\
\hline $\begin{array}{l}\text { Özel Sektör } \\
\text { Sorumluluğu }\end{array}$ & $\begin{array}{l}\text { Özel ortak tasarım inşaat } \\
\text { finansman ve bakım } \\
\text { faaliyetlerini yürütür. } \\
\text { Yemek, Kafeterya gibi } \\
\text { klinik olmayan hizmetlerin } \\
\text { sunumu da dâhil edilebilir. } \\
\text { (Daha ileri projelerde } \\
\text { laboratuvar, radyoloji gibi } \\
\text { klinik destek hizmetinin } \\
\text { verilmesi yer alır) }\end{array}$ & $\begin{array}{l}\text { Özel sektör belirli klinik } \\
\text { hizmetleri sunmayı } \\
\text { üstlenmiştir. (Klinik destek } \\
\text { hizmetleri ve özellikle } \\
\text { bakım hizmetleri gibi) }\end{array}$ & $\begin{array}{l}\text { Özel sektör tasarlama, inşa } \\
\text { etme, finansman işletme } \\
\text { hakları ile klinik hizmetler } \\
\text { ile klinik olmayan } \\
\text { hizmetleri yürütme } \\
\text { sorumluluğundadır. }\end{array}$ \\
\hline $\begin{array}{l}\text { Ortak KÖİ } \\
\text { İsimleri }\end{array}$ & $\begin{array}{l}\text { Tasarla-Yap-Finanse Et- } \\
\text { Bakımını Yap } \\
\text { Tasarla-Yap-Finanse Et- } \\
\text { Bakımını Yap- İslet } \\
\text { Tasarla-Yap-İslet-Devret } \\
\text { Özel Sektör Girisisimi } \\
\text { Altyapı KÖI'leri }\end{array}$ & $\begin{array}{l}\text { İşletme ve Yönetim } \\
\text { Sözleşmeleri }\end{array}$ & $\begin{array}{l}\text { Tasarla-Yap-İşlet-Devret } \\
\text { Klinik Servisler KÖİ } \\
\text { Enteğre KÖI } \\
\text { Kamu Özel Entegre İşbirliği } \\
\text { Alzira Model }\end{array}$ \\
\hline $\begin{array}{l}\text { Sağglık Hizm. } \\
\text { Dağıtımına } \\
\text { Etki }\end{array}$ & Düşük & & Yüksek \\
\hline
\end{tabular}

Kaynak: Abuzaineh vd. 2018: 13

KÖi uygulamalarının ilk olarak ortaya çıktığı Avrupa Birliği üyesi ülkelerde sağlık politikalarının bir parçası ve sağlık sektörünün heterojen yapısının bir gereği olarak KÖínin çeşitli şekilleri uygulanmaktadır. Buna göre, altyapı temelli model olarak adlandırılan ve Birleşik Krallık'ın öncülüğünü yaptığı ulusal sağlık sistemi tabanlı KÖi’ler, genellikle özel sektörün sağlık tesisini inşa etmesi ve ilgili hizmetleri sağlaması ve özel sektör girişimcisinin kiracısı olarak klinik hizmetlerin ulusal sağlık sistemleri tarafından sunulması esasına dayanmaktadır (European Commission, 2013: 37). Bu modelde, temel kamu hizmeti olan sağlık hizmetleri çoğu zaman kamu sektörü tarafından sunulmaktadır. Özel sektöre ise, destek hizmetleri veya ilaç kullanımı gibi hususlarda bazı görevler verilmektedir. Tesislerin ağırlıklı olarak özel sektöre ait olduğu bu sistemde, kamu idaresi yapılandırma, düzenleme ve finansal teşvikler gibi uygulamalarla özel sektör girişimcilerini desteklemektedir (McKee, Edwards ve Atun, 2006: 891).

Sağlık alanında KÖI’nin ikinci kullanım şekli olan "ayrık klinik hizmetler modeli" belirli klinik hizmetlerde yetersiz kapasiteye sahip Hindistan gibi ülkelerde uygulanmaktadır. Bu modele özel ve yüksek talep gören belirli klinik hizmetlerin kalitesinin ve bu hizmetlere erişiminin 
iyileştirilmesi ve sağıı hizmetlerinin sunumunda özel sektör katılımının arttırılması gibi amaçlarla başvurulmaktadır. (Abuzaineh Vd., 2018: 26). Bu sistemde özel sektör girişimcileriyle sadece belirli klinik hizmetlerin yürütülmesi amacıyla işbirliği yapılmaktadır.

İspanya'da Alzira model, Portekiz'de Cascais modellerinde olduğu gibi özel sektörün sağlık tesisini inşa ettiği, yönettiği ve klinik hizmetleri de sunduğu model sağlık hizmetlerinde KÖi'nin bir diğer uygulama şeklidir. "Entegre KÖi modeli" (Public-Private-Integrated Partnerships) olarak adlandırılan bu modelde özel sektör girişimcisi ulusal sağlık hizmetlerinin personelini devralmakta veya yeni personel alımına gitmektedir (European Commission, 2013: 37). illk kez 1999 yılında imzalanan bir sözleşme ile İspanya'nım Valencia şehrine bağlı Alzira kasabasında uygulandığından bu modelin ismi de "Alzira Modeli" olarak anılmaktadır. Bu modelde yapılacak sözleşmeler çerçevesinde tesisi inşa eden ve işleten özel sektör girişimcisi klinik hizmetleri de yürütmektedir (McKee, Edwards ve Atun, 2006: 891, Oxfam Brienfing Note, 2014: 4). İspanyada özellikle Valencia'da yerel hastaneler bütünüyle özel sektör tarafından yapılmakta ve işletilmektedir. Özel sektör girişimcisi bütün klinik hizmetleri ve destek hizmetlerini yürütmeyi üstlenmektedir (Biginas ve Sindakis, 2015: 6). Benzer şekilde, Portekiz KÖi uygulamalarında da klinik hizmetler ve yan hizmetler birlikte yürütülmekte ve yapım, koruma ve önemli teçhizatın temini ayrı sözleşmeler ile gerçekleştirilmektedir (Barros ve Giralt, 2009: 440 ).

Entegre KÖi modeli, kamu ve özel sektör arasında yapılan iki ayrı sözleşme ile uygulanmaktadır. Sözleşmelerden biri, klinik faaliyetleri ve temizlik, güvenlik, yemek gibi yan hizmetleri kapsarken diğer sözleşme ise, altyapı tesislerinin yapımını kapsamaktadır (Acerete, Stafford ve Stapleton, 2011: 534). Tüm bu hizmetler karşılığında kamu idaresi, özel sektör girişimcisine belirli bir ödeme yapmaktadır. Entegre KÖi modelinin, verimlilik, etkililik veya kalite terimlerinin yetersiz olduğu yerlerde daha uygun olması beklenmektedir. Bu işbirliği, özel konsorsiyuma klinik hizmetlerin sunulmasında, tasarım, finansman, yapım ve bakım gibi sağlık hizmeti üretim süreçlerinde geniş çözüm imkânları sunmaktadır (Hellowell, 2012: 71). Entegre KÖi modelinde, özel sektörün projeyi tasarlaması, finansmanını sağlaması, inşası, işletmesi ve bir veya daha fazla sağlık tesisinde klinik hizmetleri sunması, çoğu zaman bir bölge sağlık tesisinde gerçekleştirilmektedir. Bu modelde özel sektör girişimcileri veya kamu idaresi, belirlenen hizmet kalite standartlarını sağlamada tek başına sorumluluk sahibi değildir. Bu imtiyaz düzenlemesinde özel sektör kamu tesisini işletmekte ve yönetmektedir (The Global Health Group University of California, 2010: 10).

\subsection{YKD Modelinin Yapısı ve Temel Özellikleri}

Türkiye' de şehir hastanelerinde uygulanmakta olan YKD modeli, KÖi'nin "altyapı temelli model" $i$ olup Birleşik Krallık uygulamasına dayanmaktadır. Bu bağlamda, YKD modeli kamu hizmetleri için kamu ve özel sektör girişimcileri arasındaki işbirliğini ifade etmekte ve işbirliği yapan taraflar arasında risk, kazanç ve yükümlülüklerin paylaşılması ile karakterize edilmektedir (6428 Sayılı Kanun'un genel gerekçesi, 2014). YKD modelinde öncelikle kamu idaresi proje ihtiyacını belirlemekte gerekli araştırma, inceleme ve fizibilite çalışmalarından sonra nasıl bir proje gerçekleştirileceğini tanımlamaktadır. Bakanlık tarafından hazırlanan ön fizibilite raporu ve proje ile ilgili diğer belgeler Yüksek planlama Kurulu'nun (YPK) onayına sunulmaktadır. Sağlık Bakanlığı YPK'nın onayı alındıktan sonra gerek projeye özel sektör girişimcilerinin işbirliği taleplerini arttırmak gerekse sözleşme süresi boyunca çeşitli risklere karşı onları korumak amacıyla bir takım teşvik ve güvencelerle işbirliği yapacağı özel sektör girişimcilerini aramaya başlamaktadır. Tercih edilen ihale yöntemiyle özel sektör girişimcisinin 
seçilmesinden sonra projenin tasarlanması, gerekli finansmanın sağlanması ve projenin fiziki yapısının oluşturulması sorumluluğunu özel sektör girişimcisi üstlenmektedir. Sözleşme süresi boyunca projenin sahibi olan özel sektör girişimcisi tesisteki kendisine verilen destek hizmetlerinin yürütülmesi, tesisin sürekli olarak hizmette kalması için gereken bakım ve onarımların yapılması ve ticari hizmet alanlarının işletilmesi iş ve işlemlerini yürütmektedir. Özel sektör girişimcisi aynı zamanda sözleşme süresi boyunca tesisin sahibidir. Sağlık Bakanlığının temel fonksiyonu ise, tesisin kurulmasında amaçlanan asıl hizmeti ve özel sektöre bırakılmayan hizmetleri yürütmek, özel sektör girişimcilerinin iş ve işlemlerini denetlemek ve genel anlamda kamu hizmetlerinin sağlıklı ve kesintisiz olarak yürütülmesini sağlamaktır (Şekil: 2).

YKD modelinde projenin finansman yükümlülüğü özel sektör girişimcisi üzerindedir. YiD, yap-sahip ol-işlet-devret (YSiD) ve Yi gibi modellerde tesisin işletilmesi tamamen özel sektöre ait olmasına rağmen YKD modelinde kamu ve özel sektör birlikte tesisi işletmektedirler. Ayrıca, KÖI'nin diğer modelleri genelde ulaştırma alanında yoğun olarak kullanılırken, YKD modeli ulaştırmayla birlikte sosyal altyapı tesisleri (hastane, okul, sosyal konutlar, kamu binaları vb.) için de kullanılan bir modeldir. YKD Modelinin temel özellikleri asıl hizmet ve destek hizmetleri ayrımı, özel sektör kişilerine ödenecek bedeller, risk paylaşımı, ticari hizmet alanları, özel amaçlı şirket ve üst hakkı ile hazinenin borç üstlenmesi başıkklarında incelenebilir.

Şekil 2: YKD Modeli Yapısı ve İ̧sleyişi Şekli

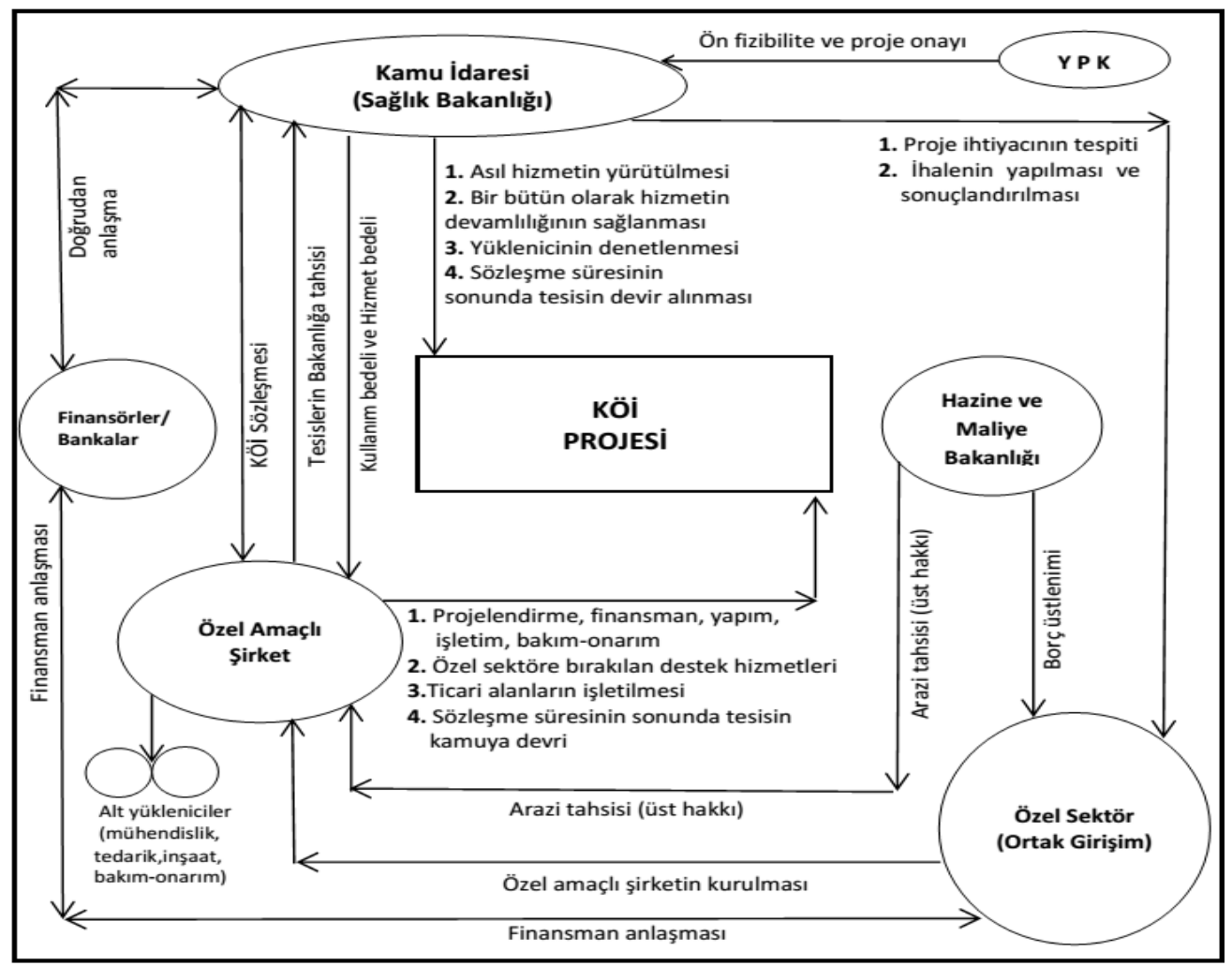

Kaynak: Şehir hastaneleri uygulamaları ve ilgili mevzuat hükümlerinden ve uygulamalardan derlenmiştir 


\subsubsection{Asıl Hizmet ve Destek Hizmetleri Ayrımı}

Şehir hastanelerinde uygulanan YKD modelinin en öne çıkan özelliği, sağlık hizmetlerinin asıl hizmet ve yan hizmetler olarak ayrılmasıdır. Buna göre, asıl hizmet olan sağlık hizmeti Sağlık Bakanlığı tarafından ve kamu görevlilerince sunulurken, tesiste asıl hizmet dışında kalan yemek, güvenlik, temizlik, ilaçlama, bakım-onarım, otopark gibi destek hizmetleri de özel sektör girişimcileri tarafından sunulmaktadır. Böylece, özel sektör girişimcisine asıl hizmetle iç içe yürütülmek zorunda olunan ve asıl hizmete destek niteliğindeki hizmetlerin yürütülmesi sorumluluğu verilerek kârı güvence altına alan bir faaliyet alanı bırakılmaktadır.

21.03.2014 tarihli ve 6282 Sayılı Sağlık Bakanlığınca Kamu Özel İşbirliği Modeli ile Tesis Yaptırılması, Yenilenmesi ve Hizmet Alanlarına Dair Uygulama Yönetmeliği'nde tesisin ve ekipmanların kullanıma hazır tutulmasına yönelik bakım, onarım gibi hizmet alımı yoluyla gördürülebilecek hizmetler "mecburi hizmetler" ve "ihtiyari hizmetler" olarak ayrılmıştır. Buna göre, bina ve arazi hizmetleri, yer ve bahçe bakım hizmetleri ile olağanüstü bakım onarım hizmetleri mecburi hizmetler olarak tanımlanmıştır. Bu hizmetler, tesisinin ve ekipmanlarının kullanıma hazır tutulmasına yönelik olan Sağlık Bakanlığı tarafından ihale dokümanında belirlenen ve özel sektör girişimcisi tarafından yerine getirilmesi zorunlu olan hizmetlerdir. Ihtiyari hizmetler ise, ihale dokümanında belirlenen temizlik, güvenlik, otopark, laboratuvar, görüntüleme ve benzeri destek hizmetleridir. Bu hizmetlerin yükleniciye verilip verilmeyeceği Sağlık Bakanlığı'nın takdirine bırakılmıştır.

Konu Adana Şehir Hastanesi özelinde incelendiğinde, özel amaçlı şirket olan ADN PPP A.Ş’nin "mecburi hizmetler" ve "ihtiyari hizmetler" şeklinde sınıflandırılan hizmetlerin yönetiminden sorumlu olduğu; yer ve bahçe hizmetleri, bina ve arazi hizmetleri, olağandışı bakım ve onarım hizmetleri, ortak hizmetler, mobilya hizmetleri ve diğer tıbbi ekipman hizmetlerinin şirket tarafından yürütülmesinin zorunlu olduğu görülmektedir. Özel sektöre bırakılıp bırakılmayacağı Sağlık Bakanlığı'nın takdirinde olan ihtiyari hizmetler ise, tıbbi hizmetler, tıbbi olmayan hizmetler ve hastane bilgi yönetim sistemi olarak ayrılmıştır. Tıbbi hizmetler, tıbbi görüntüleme, laboratuvar, sterilizasyon ve rehabilitasyon hizmetlerinden oluşurken, tıbbi destek hizmetleri dezenfeksiyon, otopark, temizlik, atık yönetimi, danışma, çamaşır, yemek ve güvenlik hizmetlerinden oluşmaktadır (Ankara Etlik Hastane Sağlık Hizmetleri İ̧̧letme Yatırım A.Ş, 2014: 34) (Şekil 3). 
Şekil 3: Şehir Hastanelerinde Özel Sektör Tarafından Yürütülecek Iş ve Faaliyetler

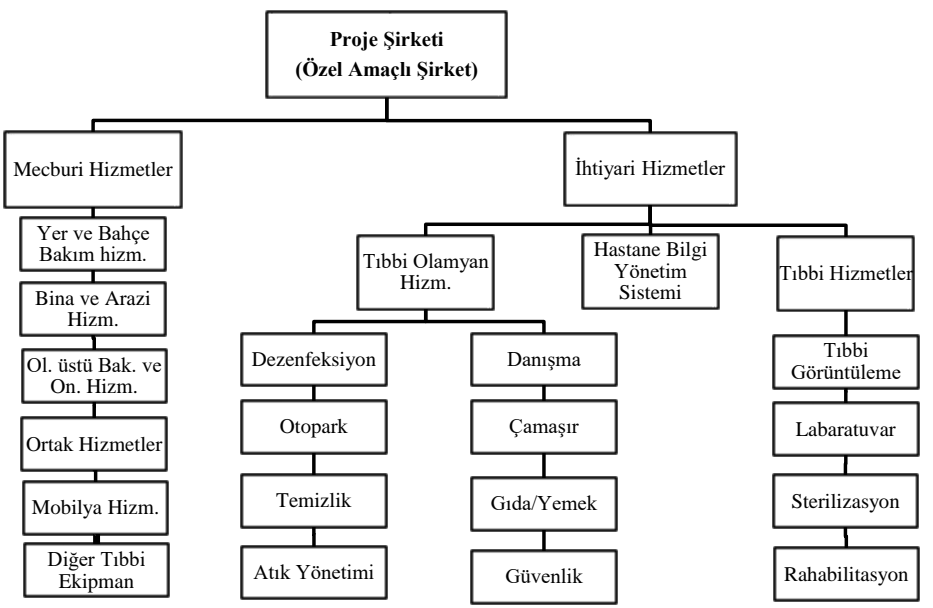

Kaynak: Ankara Etlik Hastane Sağlık Hizmetleri İşletme Yatırım A.Ş, 2014: 34

YKD modelinde asıl hizmet olan sağlık hizmetinin kamu görevlileri tarafından, destek hizmetlerin de özel sektör personelleri tarafında yürütülmesi esasına dayanan bu görev paylaşımı aynı tesiste farklı organizasyon yapılarıyla örgütlenmiş ve görev alanları belirlenmiş kamu ve özel sektör görevlilerinin birlikte faaliyette bulunması zorunluluğunu beraberinde getirmiştir. Buna göre, şehir hastanelerinde hastane yönetimi Sağlık Bakanlığı ve özel sektör girişimcisi tarafından paylaşılmaktadır. Doktor ve sağlık destek personelinin sağlanması ve klinik hastane faaliyetlerinin genel yönetimi Sağlık Bakanlığı tarafından sağlanan idari personeller tarafından yürütülmektedir. Sağlık Bakanlı̆̆ı'nın atadığı idari personel özel sektör girişimcisine verilen görevlerin dışındaki görevlerden de sorumludur. Kamu hizmetinin asıl hizmeti durumunda olan sağlık hizmetlerinin yürütülmesi için de zorunlu olarak kamu personellerinin kendi içinde bir teşkilatlanma oluşturulmuştur (ADN PPP Sağlık Yatırım AŞ, 2014: 13). 
Şekil 4: Şehir Hastanelerinde Sağlık Bakanlığının Sorumluluğu Altındaki Yönetim Organizasyonu

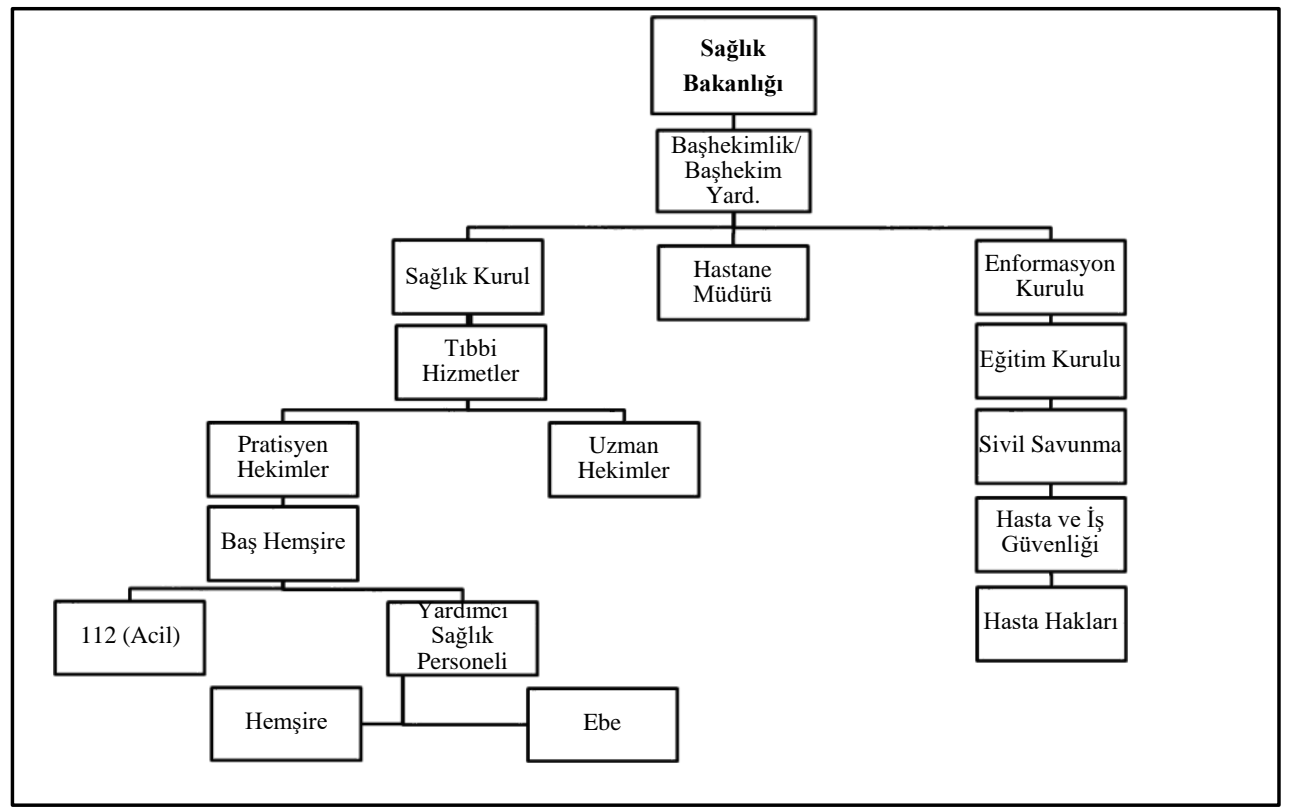

Kaynak: Ankara Etlik Hastane Sağlık Hizmetleri İşletme Yatırım A.Ş, 2014: 34

Şekil 4'te şehir hastanelerinde Sağlık Bakanlığı'nın sorumluluğu altındaki yönetim kısmının organizasyon yapısı görülmektedir. Buna göre, Bakanlığın yürüteceği hizmetlerin hastane içinde bağlı olduğu birim başhekimlik veya başhekim yardımcılığıdır. Başhekimliğe bağlı olarak çalışan bir tarafta, enformasyon kurulu, eğitim kurulu ve sivil savunma gibi birimler yer alırken, diğer tarafta da sağ ıı kuruluna bağlı olarak faaliyet yürüten sağlık personelleri ve yardımcı sağlık personelleri yer almaktadır (Ankara Etlik Hastane Sağlık Hizmetleri isşletme Yatırım A.Ş, 2014: 34).

\subsection{2. Özel Sektör Girişimcilerine Ödenecek Bedeller}

6428 sayılı kanuna göre, YKD modelinde Sağlık Bakanlığı tarafından yükleniciye ödenecek bedel, "kullanım bedeli" ve "hizmet bedeli"nin toplamından oluşmaktadır. Kullanım bedeli, tesislerin kullanımı karşııı̆ında dönemsel olarak Bakanlık tarafından özel sektör girişimcisine ödenen ve sözleşmede belirlenen bedeldir. Sözleşme süresince Bakanlığın özel sektör girişimcisine önceden belirlenmiş zamanlarda tesislerin kullanımı için ödediği kullanım bedeli, yatırımın geri ödeme metodudur ve özel sektör girişimcisinin ödülüdür (Shukla, Panchal ve Shah, 2014: 140). YKD modelinde tesisin yapımı aşamasında herhangi bir maliyete katlanmak zorunda olmayan Sağlık Bakanlı̆̆ı, tesisi inşa eden özel sektör girişimcisine kullanım bedeli ödeyerek katlandığı maliyeti uzun vadeye yaymaktadır. Kullanım bedeli yüklenici tarafından yapılan tesisin Sağlık Bakanlığı tarafından kullanımı karşılığında özel sektör girişimcisine sözleşme süresince uzun vadede ödenen kira bedeli olarak da nitelendirilebilir. Bu bedel özel hukukta yer alan kira sözleşmelerinde olduğu gibi tesisi inşa eden ve onun sahibi olmakla birlikte kamu hizmetine tahsis eden özel sektör girişimcisinin tesisin finansman riskini üstlenmesi karşılığında Bakanlıktan tahsil ettiği bir bedeldir. 6428 sayılı kanun yürürlüğe girmeden önce YKD modelini düzenleyen 5396 Sayılı Sağlık Hizmetleri Temel Kanununa Bir Ek 
Madde Eklenmesi Hakkında Kanun'da kullanım bedeli için "kira bedeli" tabiri kullanılmıştır. 6428 Sayılı Kanun kira bedelinin özünde önemli bir değişiklik getirmeden ismini "kullanım bedeli" olarak düzenlemiştir.

Kullanım bedeli, dönem sonunda Türkiye İstatistik Kurumunca belirlenen dönemsel Üretici Fiyat Endeksi ile Tüketici Fiyat Endeksi toplamının yarısı oranında arttırılmaktadır. Bu bedel her yıl üçer aylık dönemlere tekabül eden peşin ödemeler şeklinde yapılmaktadır. Ödemeler, Ocak-Mart dönemi için Ocak ayında, Nisan-Haziran dönemi için Nisan ayında, Temmuz-Eylül dönemi için Temmuz ayında ve Ekim-Aralık dönemi için Ekim ayında gerçekleştirilmektedir.

Özel sektör girişimcisine ödenen ikinci bedel "hizmet bedeli"dir. Bu bedel, tesisin ve ekipmanların kullanıma hazır tutulmasına yönelik bakım, onarım ve benzeri hizmetlerin bedeli ile ilgili mevzuata göre hizmet alımı yoluyla gördürülebilecek hizmetlerin sunulması karşıı̆ı̆ında Sağlık Bakanlığı tarafından özel sektör girişimcisine ödenmektedir. Hizmet bedeli, beş yıl ve ihtiyari hizmetlerde sözleşmede yer alan miktara bağlı, tıbbi destek hizmetlerinde ise on yılı geçmemek üzere dönemsel piyasa testi ile güncellenmektedir.

6428 Sayılı Kanun'a göre, proje için hazırlanacak ön fizibilite raporunda özel sektör girişimcisine ödenecek kullanım bedeli ve hizmet bedellerinin de belirtilmesi gerekmektedir. Sözleşme süresinin tespitinde göz önünde bulundurulacak hususlar, bedellerin tespitinde de dikkate alınmaktadır. Kamu hizmetlerinin klasik usulle yürütülmesinden farklı olarak YKD modelinde yapım işinin tamamlanmasından önce hiçbir şekilde bedel ödemesi yapılamamaktadır. Fakat aşama tamamlamaları ve kısmi hizmete alınma halinde Sağlık Bakanlığı tarafından yapılacak kısmi kabullere ilişkin sözleşme hükümlerine göre bir bedel ödenmesi öngörülmüşse, öngörülen bedel ödemesi yapılabilmektedir.

Şehir hastanelerinde kullanım ve hizmet bedeli ödemeleri Sağlık Bakanlığı'na veya bağlı kuruluşlara ait döner sermaye bütçesinden ve/veya merkezi yönetim bütçesinden ödenmektedir. Ödemeler Sağlık Bakanlığı ve özel sektör girişimcileri arasında imzalanan sözleşme hükümleri çerçevesinde yapılmaktadır. Özel sektör girişimcisinin sözleşme süresince öz kaynakları dışında finansal tablosunda belirtilen toplam borç miktarında yeniden finansman ve/veya borç yapılandırması suretiyle azalma meydana gelmesi durumunda borç miktarındaki azalma Sağlık Bakanlığı ve özel sektör girişimcileri arasında eşit oranda taksim edilerek kullanım bedeline yansıtılmaktadır.

\subsubsection{Ticari Hizmet Alanları}

6428 Sayılı Kanun'da, şehir hastaneleri yerleşkesi içerisinde yer alacak ticari hizmet alanları "mecburi ticari hizmet alanları" ve "ihtiyari ticari hizmet alanları" olarak ayrılmaktadır. Buna göre, kamu idaresi ve özel sektör girişimcisi tarafından piyasa rayiç fiyatlarına göre belirlenen ücret karşılığında tesisin yerleşkesinde bulunan ve hizmetten yararlananların ihtiyaçlarını karşıladıkları, tesisin mahiyetine göre yapılması idarece zorunlu tutulan ve ihale dokümanında belirlenen hizmet alanları "mecburi ticari hizmet alanları" olarak adlandırılmaktadır. Mecburi ticari hizmet alanları dışında Sağlık Bakanlığı'nın ihale dokümanı ile belirleyeceği esaslara göre yerleşkede yapılacak her türlü hizmet alanları da "ihtiyari ticari hizmet alanları" olarak tanımlanmaktadır. Sosyal tesisler, oteller, restoranlar, alışveriş merkezleri gibi ticari alanlardan hangilerinin mecburi, hangilerinin isteğe bağlı olduğunun ihale dokümanında belirtilmesi gerekmektedir. 


\subsubsection{Risk Paylaşımı}

YKD modelinin diğer bir ayırt edici özelliği risk paylaşımıdır. YKD taraflardan en az birisinin kamu kuruluşu olduğu iki veya daha fazla katılımcı tarafı içermekte ve taraflara örgütsel yükümlülük yüklemektedir. Tarafların geliştirdikleri işbirliği ile finansal, ekonomik, çevresel ve sosyal sonuçlara yönelik riskler ve sorumluklar paylaşılmaktadır (Grimsey ve Lewis, 2004: 13). YKD modelinde ne özelleştirilmede olduğu gibi kamu hizmeti risklerinin tamamı özel sektöre devredilmekte ne de kamu hizmetinin tamamen kamu sektörü tarafından yürütülmesinde olduğu gibi risklerin tamamı kamu sektörü üzerinde kalmaktadır. YKD bu iki ucun ortasında kalmakta olduğundan riskler de kamu ve özel sektör arasında dengeli bir şekilde dağıtılmıştır. Risk paylaşımında en önemli kural, bir riski en iyi hangi taraf yönetebilecekse o riskin o tarafa verilmesidir. Bir projenin devamlılığının sağlanmasında en önemli risklerden olan talep riski genellikle kamu sektörü tarafından, finansman, inşaat, işletme ve bakım riskleri de özel sektör tarafından üstlenilmektedir.

Finansman riski özel sektöre ait olmakla birlikte finans kuruluşlarınca sağlanan sermayeye çoğu zaman hazine tarafından çeşitli garantiler verilmektedir. YKD modelinde proje finansmanı konusunda kamu sektörünün temel fonksiyonu, özel sektör kişisine bir takım güvenceler sağlamasından ibarettir. Modelde finansman yükümlülüğü esas olarak özel sektör girişimcisinindir. Bu yöntemle YKD modelinin yüklenicisi proje finansmanı ve inşaat süresindeki sorumluluğu üstlenir. Tabi ki bu sorumluluk yüklenici tarafından ücretsiz olarak üstlenilmemekte, gelen maliyet kamu idaresi tarafına aktarılmaktadır (Shukla, Panchal ve Shah, 2014: 140).

\subsection{5. Özel Amaçlı Şirket (Special Purpose Vehicle ) ve Üst Hakkı}

YKD modelinde ihaleyi kazanan özel sektör girişimcileri faaliyet alanı KÖi projesi ile sınırlı olan özel amaçlı bir şirket kurarlar. KÖi sözleşmesi kurulan özel amaçlı şirket ile kamu idaresi arasında yapılmaktadır. Ayrıca, şehir hastaneleri ve ticari hizmet alanları, hazinenin mülkiyetindeki taşınmazlar üzerinde yaptırılmaktadır. Bunun için Sağlık Bakanlığı'nın talebi üzerine hazinenin özel mülkiyetindeki taşınmazlardan veya devletin hüküm ve tasarrufu altında bulunup tescili mümkün olan yerler üzerinde tesis yapılabilmektedir. Üzerine tesis yapılacak hazine arazisinin mülkiyeti yine Hazinede kalmakla birlikte özel amaçlı şirket lehine üst hakkı tesis edilmektedir. Üst hakkının, yatırım dönemi hariç otuz yılı geçmemek üzere sözleşme süresi boyunca bedelsiz olarak bağımsız ve sürekli nitelikte tesis edilmesi gerekmektedir. Üst hakkı tesis edilerek yükleniciye teslim edilen taşınmazlar sözleşme süresince amacı dışında kullanılamamakta ve üst hakkı Hazine ve Maliye Bakanlığı ile Sağlık Bakanlığı'nın izni olmaksızın devredilememektedir.

\subsubsection{Hazinenin Borç Üstlenmesi}

Diğer KÖi modellerinde de uygulanan hazinenin borç üstlenmesi, YKD modelinde çeşitli amaçlar için kabul edilen bir yöntem olup, tesisi inşa eden özel sektör girişimcisinin öz kaynakları dışında kullandığı kredilerin hazine tarafından üstlenilmesi şeklinde uygulanmaktadır. 28.3.2002 tarihli ve 4749 Sayılı Kamu Finansmanı ve Borç Yönetiminin Düzenlenmesi Hakkında Kanun'nun 8/A maddesine göre, genel bütçe kapsamındaki kamu idareleri ile özel bütçeli idareler tarafından yürütülen bazı yatırım ve hizmetlere ilişkin uygulama sözleşmelerinin süresinden önce feshedilerek tesisin ilgili idareler tarafından devralınması durumunda, söz konusu yatırım ve hizmetler için yurt dışından sağlanan 
finansman ve varsa bu finansmanın teminine yönelik türev ürünlerden kaynaklananlar da dâhil olmak üzere mali yükümlülükler Hazine ve Maliye Bakanlığı tarafından üstlenilebilir.

Borç üstlenimi, 6428 Sayılı Kanun hükümlerine göre YKD modeli ile gerçekleştirilmesi planlanan ve tutarı asgari beş yüz milyon Türk Lirası olması öngörülen yatırım ve hizmetlere ilişkin uygulama sözleşmelerinden kaynaklanan mali yükümlülükler için geçerlidir.

\section{3. Şehir Hastaneleri ve Sağlık Hizmetlerinin Dönüşümü}

\subsection{YKD Modelinin Tercih Edilmesinde Etkili Olan Faktörler}

Türkiye'de sağlık tesislerinin fiziksel kapasite yetersizliği, sağlık hizmetleri finansmanının bütçe üzerinde oluşturduğu baskı, özel sektörün tecrübesinden yararlanmak isteği ve düşük kalite standartları YKD modelinin tercih edilmesinde rol oynayan en önemli faktörlerdir. TBMM Plan ve Bütçe Komisyonu Raporu'nda belirtildiği üzere, Türkiye'nin sağlık altyapısı fiziksel kapasite açısından henüz yeterli seviyeye ulaşamamış, fiziksel kapasite üretimi ve yatak sayıları itibari ile $A B$ ve OECD ülkeleri ortalamasının oldukça gerisinde kalmıştır (TBMM Plan ve Bütçe Komisyonu, 2005: 1). Türkiye'de birçok sağlık tesisinin kapasitesinin sınırlı olması ve yetersiz fiziksel kapasitenin genişletilmesi olanağının bulunmaması; hastanelerin yeterli park ve yeşil alana sahip olmamaları; eski hastanelerin mevcut fiziksel yapılarını etkin biçimde tamir etmenin ve yenilemenin oldukça zor olması; ameliyat odası, yoğun bakım, acil müdahale, laboratuvar, görüntüleme merkezi, poliklinik gibi hizmet birimlerinin fiziksel yapı ve donanım açısından hastane standartlarını karşılamaması gibi sebeplerle yeni sağlık yatırımlarının gerçekleştirilmesine ihtiyaç duyulmuştur (ADN PPP Sağlık Yatırımları AŞ, 2014: 6).

Grafik 1'de Türkiye'nin ve diğer bazı ülkelerin 10 bin kişiye düşen hastane yatak sayıları görülmektedir. Buna göre, Türkiye 10 bin kişiye düşen 27,9 hastane yatağı ile Japonya, Güney Kore ve Almanya gibi ülkelerin oldukça gerisinde kalmakta ve $A B$ ülkeleri ortalamasının yaklaşık yarısına yakın bir değere sahip olmaktadır (Sağlık Bakanlığı, 2018: 118). Bu veriler, Türkiye'de daha çok sağlık tesisleri yapılması zorunluluğunu ortaya koymaktadır.

Grafik 1: 10 Bin Kişiye Düşen Hastane Yatağı Sayısının Uluslararası Karşılaştırması (2017 Yılı)

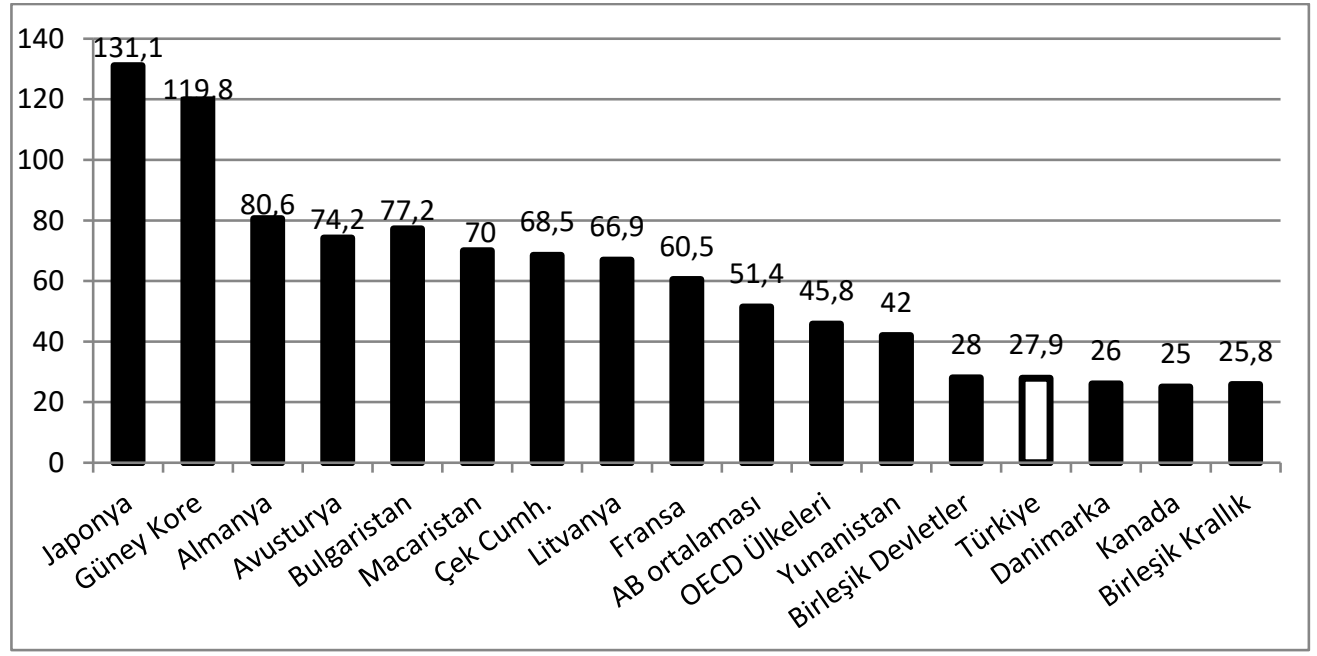

(Kaynak: Sağlık Bakanlığı, 2018: 118)

Not: Türkiye verisi 2017 yılına aittir. Ülke verileri 2016 yılına veya en yakın yıla aittir 
Türkiye'de YKD modelinin tercih edilmesinde sağlık tesislerinin fiziki kapasitesinin artırtılmasının yanında hastane inşaat sürelerinin kısaltılması amacı da temel faktörlerden biri olmuştur. 2004 yılı verilerine göre, Sağlık Bakanlığı hastanelerinin inşasının ortalama 7 yıl sürdügünü tespit edilmiştir. Son dönemde inşa edilen hastane örneklerinde büyük ilerlemeler kaydedilmekle birlikte hem inşa süresi hem hastane yapı kalitesi hem de hastane işletmeciliği açısından yetersizlikler yaşanabilmektedir. Klasik yönetim modeliyle yürütülen sağlık hizmetlerinde bunlar gibi aksaklıkların tam olarak giderilmesi mümkün görülmediğinden model arayışlarına gidilmiş YKD modeli ile başarılı ve sürdürülebilir işletmeler oluşturma çabalarına hız verilmiştir (Aydın, 2015: 15).

Ayrıca, nüfus artışı, nüfusun niteliği ve özellikle yaşlı nüfus oranlarındaki artış sağlık harcamalarının her geçen yıl daha fazla artmasına sebep olmaktadır (Mendelson ve Schwartz, 1993: 123). Kronik hastalıkların ve yetersizliklerin artması, sağlıkta hizmetlerinde yüksek maliyetli ileri teknoloji kullanımı, sağlığın emek yoğun bir sektör olması, sağılk bilincinin artması, gelir artışına bağlı olarak sağlık harcamaları talebinin artması, arzın talep yaratması ve asimetrik bilgiye bağlı problemler de sağıık harcamalarının artmasına sebep olmaktadır (Kılavuz; 2010: 174). Bu sebeplere bağlı olarak, sağlık harcamalarının GSYiH'den daha hızlı arttığı ve kamu bütçeleri üzerinde önemli oranda baskı oluşturduğu günümüzde hükümetler özellikle sağıı alanındaki yatırımların gerçekleştirilmesinde gün geçtikçe daha fazla özel sektörle işbirliği içinde olmaya özen göstermektedir (Health Research Institute, 2010: 5).

Türkiye'de kamu sağlık harcamalarının düzenli olarak arttı̆̆ı görülmektedir. Buna göre, 2002 yılında 13.270 milyon TL olan sağlık harcamaları 2003'de 17.462 milyon TL'ye çıkmıştır. Yıllar itibariyle artış gösteren kamu sağlık cari ve yatırım harcamaları 2004'de 21.389 milyon TL, 2005'te 23.987 milyon TL, 2006'da 30.116 milyon TL olarak gerçekleşmiştir. Harcamalar sürekli artış göstererek 2017'de 109.744 milyon TL'ye ulaşmıştır (Sağlık Bakanlığı, 2018: 246). Artan nüfus ve kentleşmeyle birlikte büyüyen sağlık altyapı ihtiyacına karşılık yatırım projelerinin finansmanında yenilikçi yöntemlerin geliştirilmesi yoluna gidilmiştir (TC Başbakanlık Devlet Planlama Teşkilatı Müsteşarlığı 2009-2013 Stratejik Planı, 2009: 50-54). Türkiye'nin sağlık alanındaki mevcut durumuyla ilgili bir gösterge sağlık harcamalarının GSMH'ye oranıdır. 2013 yılında Türkiye'de toplam sağlık harcamalarına GSMH'nin \%5.1'i ayrılmıştır. Bu alanda OECD ortalaması \%8,9 olup, Türkiye OECD ülkeleri arasında en düşük orana sahiptir. Bu oran ABD'de \%16,4, Hollanda ve İsviçre'de \%11,1, İsveç ve Almanya'da \%11 seviyesindedir (OECD Health Statistics, 2015: 2). Bu bağlamda, finansman sorununun aşılabilmesi için YKD modeli gibi alternatif kaynaklardan yararlanmak bir tercihten ziyade bir zorunluk olarak değerlendirilmektedir.

Son dönemlerde YKD modelinin tercih edilmesindeki finansmanla ilgili gerekçeler, kamudaki idari ve mali açıdan yaşanan değişimlerle de ifade edilmektedir. Vergiler, uluslararası kurumlardan sağlanan finansmanlar, iç ve dış borçlanma gibi kamu gelirlerin kamuya sürekli bir kaynak olmalarına rağmen, etkinliklerini yitirmeleri YKD modeline ilginin artmasına sebep olmuştur. Özellikle dolaysız vergiler ve kurumlar vergisinin toplam vergi tahakkuku içindeki payının giderek azalması kamu gelirlerinin önemli bir payını oluşturan vergi gelirlerinin belli bir seviyede kalmasına neden olmaktadır. Benzer şekilde, uluslararası kurumlardan sağlanan resmi yardımlar ve krediler de son yıllarda bir gelir kalemi olmaktan çıkma eğilimindedir. İç borçlanma olanakları da belli bir seviyede kalmaktadır (Yılmaz ve Karakaş, 2011 ) Bu bağlamda, YKD altyapı tesislerinin özel sektör tarafından yapılmasına ve özel sektörün giderlerinin tesisin döner sermayesinden elde edilen gelirlerle ve uzun yıllara 
yayılmış şekilde ödenmesine imkân vermesiyle yaşanan finansman sıkıntısına çözüm üretmede alternatif bir yöntem olarak değerlendirilmektedir.

YKD modelinin tercih edilmesinde diğer bir faktör kamu sağlık yatırım projelerinin yapım ve işletmesinde özel sektör dinamizmi ve verimliliğinden faydalanma amacıdır. Bu bağlamda, YKD modeli gelecek yıllarda kamu yatırımlarına ayrılabilen kaynakların çeşitlendirilmesi ve uygulamada etkinliğin sağlanması açısından önemli bir fırsat olarak değerlendirilmektedir (TC Başbakanlık Devlet Planlama Teşkilatı Müsteşarlığı 2009-2013 Stratejik Planı, 2009: 50-54).

YKD modeliyle ülkenin tamamında sağıı hizmetlerinin kalite ve verimliliğinin arttırılması konusunda bir takım amaçlara ulaşılması hedeflenmiştir. Bu amaçlar, tedavi çeşitliliğini yaygınlaştırmak ve sağlık hizmetlerine kolay erişimi sağlamak, sağlık alanında bölgesel gelişime katkıda bulunmak, sağlık hizmetlerini uygun maliyetle, son teknolojik imkanlarla ve kaliteli işgücüyle sunmak, günübirlik cerrahi gibi tedavi edici uygulamaların benimsenmesidir. Sağlık hizmetlerinde kalite ve verimliliğin arttırılmasının hastaların hastanede yatış süresinin kısaltılması, yeni tedavi teknolojilerinin uygulanması, sevklerin ve enfeksiyonların azaltılması, hasta güvenliğinin ve memnuniyetinin arttırılması şeklinde pozitif etkilerinin olması öngörülmüştür. Çalışanlar açısından ise, bölge üzerine uzmanlaşmış ekipler tarafından hizmet verilmesi, çalışanların güvenliğinin, memnuniyetinin ve hizmet kalitesinin arttırılması, sağlık hizmeti performansının yükseltilmesi amaçlanmıştır (ADN PPP Sağlık Yatırımları AŞ, 2014: 2). Ayrıca, son dönemlerde özel sektör tarafından sosyal hizmet alanlarındaki altyapı hizmetlerine duyulan ilginin artması, organizasyon ve hizmet sunmada kamu ve özel sektör arasındaki tamamlayıcı olma fikrinin gelişmesi YKD’nin tercih edilmesinde rol oynayan faktörlerdendir (Constantinescu, 2012: 35).

Yukarıda sayılan faktörlerin etkisi ile 2003 yılında sağlık alanında köklü reformlar içeren "Sağlıkta Dönüşüm Programı" başlatılmış ve sağlık hizmetlerinde YKD modelinin temel esasları belirlenmiştir. Insan merkezlilik, sürdürülebilirlik, sürekli kalite gelişimi, katılımcılık, uzlaşmacılık, gönüllülük, güçler ayrılığı, desatralizasyon ve hizmette rekabet gibi ilkeler üzerinde hayata geçirilmesi planlanan bu programda Sağlık Bakanlığı'nın planlayıcı ve denetleyici yönü vurgulanmış, erişimi kolay ve güler yüzlü sağlık hizmeti ile nitelikli ve etkili sağlık hizmetleri gibi bileşenler belirlenmiştir (Sağlık Bakanlığı, 2003: 25). Sağlıkta Dönüşüm Programı ile sağıı hizmetlerinin etkili bir biçimde sunulması ve vatandaşların sağlık hizmetlerine kolay ve eşit biçimde ulaşabilmelerinin sağlanması amaçlanmıştır. Programla nitelikli sağlık hizmetlerinin sunumu amacıyla mevcut tesislerin yerine modern sağlık tesislerinin inşa edilmesi planlanmıştır (Sağlık Bakanlığı, 2010: 75). İnşa edilecek sağlık tesislerinin de YKD modeliyle gerçekleştirilmesi ve özel sektör girişimcilerinin sağlık hizmetlerinde daha fazla rol üstlenmesi planlanmıştır.

\section{2. Şehir Hastanelerinin Sağlık Hizmetlerinin Dönüşümüne Etkisi}

Türkiye'de 2018 sonu itibariyle sözleşmesi imzalanmış 21 şehir hastanesi bulunmaktadır. Bu hastanelerden Adana (1.550 yataklı), Elazığ (1.038 yataklı), Eskişehir (1.081 yataklı), Isparta (755 yataklı), Kayseri (1.607 yataklı), Manisa (558 yataklı), Mersin (1.300 yataklı), Yozgat (475 yataklı) şehir hastaneleri olmak üzere sekizi hizmete alınmış ve bu hastanelerde fiilen işletme dönemine geçilmiştir. Hizmete açılan hastanelerin toplam yatak sayısı 8.364 dür. Ankara Bilkent (3.704 yataklı), Ankara Etlik (3.577 yataklı) ve Bursa (1.355 yataklı) Şehir Hastaneleri'nin 2019'da hizmete açılması planlanmaktadır. 2019'da hizmete girecek bu 3 (üç) şehir hastanesinin toplan yatak sayısı 8.636'dır. 2020'de hizmete alınması planlanan 9 (dokuz) şehir hastanesinin 12.115 ve 2021'de hizmete alınması planlanan 1 (bir) şehir hastanesinin de 
1.700 yatak kapasitesi bulunmaktadır. Böylece, mevcut hizmete alınmış 8.364 yatak kapasitesine sahip 8 hastane ile birlikte 2021'e kadar hizmete alınacak 13 şehir hastanelerinin toplam yatak sayısının 30.815 olması planlanmaktadır (Sağlık Bakanlığı, 2019)

Türkiye'de YKD modeliyle inşa edilen ve hizmete alınmaya başlanan şehir hastaneleri sağıık hizmetleri alanında gerçekleştirilen en büyük ve radikal değişimlerden biridir. 2017 yılında şehir hastanelerinin hizmete açılması ile başlayan yeni dönemi "Şehir Hastaneleri Dönemi" diye isimlendirmek mümkündür (Sağlık-Sen Stratejik Araştırmalar Merkezi Enstitüsü, 2018: 13). Bu bağlamda, şehir hastanelerinin 10 bin kişiye düşen yatak sayısı ve nitelikli yatak sayısının arttırımasında önemli bir rol oynaması amaçlanmaktadır. 10 bin kişiye düşen yatak sayısının 2023 yılına kadar 30'a çıkarılması ve hastane yataklarının tamamının nitelikli hale getirilmesi hedeflenmekte, yeniden dönüştürülmesi amaçlanan 95 bin yatak kapasitesinin yarısının YKD modeli ile diğer yarısının ise, kamu imkânlarıyla dönüştürülmesi planlanmaktadır (Müezzinoğlu, 2015). Dönüştürülecek yatak kapasitesinin yarısının YKD modeli ile gerçekleştirilmesinin planlanması, modelin sağlık hizmetleri sunumunda ne kadar önemli bir yer tuttuğunun açık bir göstergesidir. YKD modeliyle sağlık tesislerinin inşa edilmesi altyapıdaki bu eksikliklerin giderilmesine ve kişi başına düşen yatak sayısının arttırılmasına katkı sağlamaktadır. Şehir hastaneleri ile toplamda 50 bin yatak kapasitesine ulaşılması hedeflenmekte, ilk etapta 16 ayrı projede 24 bin yatak kapasitesinin hayata geçirilmesi planlanmaktadır (Aycı, 2015).

2017 yılı verileriyle Sağlık Bakanlığı'na ait hastanelerde toplam 135.339 yatak kapasitesinin bulunduğu dikkate alındığında şehir hastaneleriyle hayata geçirilmesi planlanan toplam 50 bin yatak kapasitesinin sağlık hizmetlerinde oldukça önemli oranda yenilenmeyi beraberinde getireceği anlaşılmaktadır. Ayrıca, Sağıık Bakanlığı hastanelerinde hasta yataklarının sadece \%53.61'i (72.561 yatak) nitelikli yatak olduğundan şehir hastaneleri nitelikli yatak sayılarının arttırmasında da önemli ölçüde katkı sunmaktadır (Sağlık Bakanlığı, 2018: 114).

Nitelikli yatak sayısının artmasında katkı sağlamakta olan şehir hastaneleri enerji verimliliği, depreme dayanıkılığı, dijital özellikleri ve yüksek teknolojinin kullanıldığı altyapısıyla "akıllı hastaneler" veya "dijital hastaneler" olarak inşa edilmektedirler. Odalar, ameliyathaneler, laboratuvarlar gibi sağlık hizmeti sunulan alanlarından otopark işletmeciliğine kadar bütün alanlarda yüksek hizmet kalitesinin sağlanması amaçlanmaktadır. Bu hastanelerde bilgi sistemleri birbirleriyle bütünleşik olarak çalışabilmekte, tıbbi cihazlarla bilgi yönetim sistemine bilgi gönderebilmekte, çalışanların ve hastaların yetkileri ve onayları dahilinde bu sistemdeki bilgiye hastaneden veya uzaktan erişebilmektedir. Illk başta elle yapılan kayıt işlemlerinin ortadan kaldırılması ve kâğıt, röntgen filmi gibi malzemelerin kullanımının azaltılması ile çalışanların dokümantasyona ayırdıkları sürelerin azaltılarak bilişim teknolojilerinin hasta ve çalışan yararına kullanılması sağlanmaktadır. Hastalara ve süreçlere dair her türlü veri ve bilginin kayıt altına alınması, işlenmesi ve ilgili kişi ve birimlerin kullanımına sunulması tıbbi hataları azaltarak hastaların tanı, tedavi ve izlenmesini kolaylaştırmaktadır (Kantarcı, 2016).

Şehir hastaneleri bu özellikleriyle akıllı bina teknolojisinin dijital hastane teknolojisi ile donatılmasına imkân veren hastaneler olarak inşa edilmektedir. Bunu sağlamak için röntgenlerin, raporların ve laboratuvar ve diğer birimlerden çıkan her türlü sağlık verisinin elden ele dolaşmasının önüne geçilerek verilerin sistemin içerisinde dolaştığı ve depolandığı bir hastane sistemi kurulmaktadır. Bu hastaneler ile birlikte kamu hastane işletmeciliği ve hizmet anlayışı, özel sektörün hizmet kalite ve verimliliği ile birleştirilerek, fiziki mekânları ve 
hizmet anlayışı ile vatandaş memnuniyetini esas alan hastanelerin tesis edilmesi mümkün olabilmektedir (Kantarcı, 2016).

Şehir hastanelerinin planlama, yapım ve işletme yöntemleri göz önüne alındığında bu hastanelerin ileri teknolojinin yardımıyla kalite odaklı ve hasta memnuniyetini esas alan bir anlayışla inşa edildikleri anlaşılmaktadır. Bu hastanelerde hasta memnuniyetini klasik usul ile hizmet sunulan diğer kamu hastanelerine oranla artmıştır. Şehir hastanelerindeki fiziki şartların üst düzeyde olması ve ulaşılabilen sağlık hizmetlerinin çeşitliliği vatandaşlar tarafından oldukça olumlu karşılanmaktadır(Sağlık-Sen Stratejik Araştırmalar Merkezi Enstitüsü, 2018: 88).

$\mathrm{Bu}$ sonucu destekler nitelikte bir araştırma Gökkaya, İzgüden ve Erdem tarafından yapılmıştır. İşletme dönemine geçmiş şehir hastanelerinde hasta memnuniyet oranlarının tespitine yönelik Isparta Şehir Hastanesi'nden hizmet alan hastalar üzerinde yapılan bu araştırmada fiziksel ortam, genel memnuniyet, personel memnuniyeti ve zaman boyutu olmak üzere dört farklı boyutta hasta memnuniyet düzeyleri ölçülmüş ve hastaların hastane hizmetlerinden oldukça memnun olduğu sonucuna varılmıştır. Özellikle hastanenin araç gereç, muayene odaları, hijyen koşulları ve fiziki ortamları konularında hastaların oldukça memnun oldukları anlaşılmıştır. Araştırmaya göre, hastalar hastane genel kalitesinden, muayene olunan birimlerden ve danışma ve yönlendirme hizmetlerinden genel olarak memnundurlar. Isparta Şehir hastanesinde hastaneye ulaşım, hastane içi ulaşım, tıbbi sekreterlerin olmaması, hastane içi karışıklık/büyüklük ve otopark sorunları ise hasta memnuniyetini düşüren faktörler olarak ön plana çıkmıştır. Ayrıca, araştırmada Devlet Hastanesi, Gülkent Hastanesi ve Kadın Doğum ve Çocuk Hastalıkları Hastanesi'nin şehir hastanesine dönüşmesinden hastaların memnun oldukları sonucuna ulaşılmıştır (Gökkaya, İzgüden ve Erdem, 2017: 146).

Benzer şekilde, şehir hastanelerinden hizmet alan hastalar üzerinde yapılan başka bir araştırmada da, bu hastanelerin zamanında muayeneye başlanması, hastaların muayene sırasına göre adil olarak muayeneye alınması, muayene için yeterince zaman ayrılması, özel muayeneye yönlendirmenin yapılmaması, hastanenin fiziki koşulları (mekân, ortam ısısı, hasta muayene araçları, bekleme ortamı vb), sağlıkla ilgili ihtiyaç ve isteklerin hızı bir şekilde yerine getirilmeye çalışılması, refakatçi ve/veya hastaların gerektiğinde danışabileceği kişilere ulaşılabilmeleri, yemek kalitesi ve miktarı, görüntüleme ve laboratuvar hizmetlerinde sıra bekleme süresi, hekimler ve diğer sağlık personellerinin hasta ve yakınlarına karşı ilgili ve hoşgörülü davranmaları, sağlık hizmetinden eşit faydalanma konularında hastaların memnuniyet düzeylerinin oldukça yüksek olduğu sonucuna varılmıştır (Çınar, Türkoğlu ve Tütünsatar, 2017: 226-227).

Şehir hastanelerinin sağlık hizmetlerindeki değişim ve dönüşüme katkısının yanında, bu hastanelere çeşitli açılardan eleştiriler de yöneltilmektedir. Bu eleştiriler genel olarak;

- Şehir hastanelerinde kullanılan YKD modelinin özelleştirmeden bir farkının olmadığı ve bu model ile sağıık hizmetlerinin özel sektörün sorumluluğuna verildiği,

- YKD modeli ile yapılan tesislerde özel şirketlere oldukça büyük miktarlarda kullanım bedeli (kira) ödenerek kamu maliyesine önemli bir yük getirildiği,

- Ihale ve yapım süreçlerinin yeterince şeffaf olmadığı ve süreçlerin karmaşıklığı,

- Talep riskinin Sağlık Bakanlığı tarafından üstlenilmesi, başka bir deyişle özel sektöre garantiler verilmesinin kamu zararına yol açabileceği, 
- Finansmana hazine garantilerinin getirilmesinin bütçe üzerinde riskler oluşturacağı,

- Hastanelerin çok büyük ölçekte olmalarının koordinasyonun sağlanmasında ve işletme süreçlerinde olumsuzluklara yol açabileceği,

- Kamu ve özel sektör görevlilerinin aynı ortamda çalışmalarının çeşitli uyumsuzluklara ve aksamalara neden olabileceği,

- 25-30 yıl gibi uzun bir süre boyunca özel sektör girişimcilerine ödenecek kullanım bedelinin, yüksek maliyet içerdiği hem de şimdiki hizmetlerin gelecek kuşaklara ödettirilmesi anlamına geldiği,

- Özel sektör girişimcileriyle imzalanan uzun süreli taahhütlerin gelecek dönemlerdeki kamu görevlilerin faaliyet alanını ve imkânını daraltacağı,

- YKD modeli konusunda işletme veya yönetim tecrübesinin eksikliği,

- Amacı kamu yararını gerçekleştirmek olan kamu idaresinin ve amacı kar elde etmek olan özel sektör girişimcisinin amaçlarındaki farklılığın çeşitli olumsuzluklara yol açacağı,

- YKD modelinin klasik satın alma usullerine göre hem özel sektör hem kamu sektörü için daha yavaş süreçte gerçekleştirilebildiği,

- Şehir hastanelerinin hizmete girdiği şehirlerde bazı kamu hastanelerinin kapatılmasının ve sağlık hizmetlerin bir noktada toplanmasının vatandaşların sağlık hizmetlerine ulaşmaları konusunda bir takım zorluklarla karşılaşmalarına sebep olacağı,

- Ülke olarak şehir hastaneleri modeli konusunda henüz yeterli tecrübeye sahip olunmamasının yol açacağı olumsuzluklar şeklinde sıralanabilir.

Ayrıca, YKD Modelinde uygulamalarının muhasebeleştirilmesi ve raporlanması konusunda bazı adımların atılmasına rağmen, bu modelin muhasebeleştirilme sürecinin henüz belirli standartlara kavuşturulamadığı ve bu durumun da bütçeler üzerinde belirsizliğe sebep olduğu belirtilmektedir (IMF, 2004, 22). Konu ile ilgili Sayıştay tarafından hazırlanan Türkiye Kamu Hastaneleri Kurumu 2017 Yılı Sayıştay Denetim Raporu'nda hizmete giren şehir hastanelerinden kaynaklanan varlık ve yükümlülükler ile envanter işlemlerinin ilgili mevzuata uygun kayıt edilmediği, kira ödemelerinin hatalı muhasebeleştirildiği belirtilmektedir (Sayıştay Başkanlığı, 2018: 13)

Bir bütün olarak değerlendirildiğinde KÖi'lerin vergi mükelleflerini baskı altına alan bir yapı olarak değerlendirildiği yaklaşımlara da rastlanmaktadır. Hodge ve Greve göre, KÖi'ler “haydutun tüm ganimeti yağmalayarak kaçması”dır. KÖi uygulamalarında kamu sektörü hiçbir iş yapmayan şişman kediye, özel sektör de "şişman kedinin oğlu"na benzemektedir (Hodge ve Greve, 2007: 549). Modele eleştirel yaklaşanlar bazı başarısız KÖi uygulamalarını örnek göstererek KÖi yerine klasik satın alma yöntemlerinin tercih edilmesi gerektiğini vurgulamaktadırlar.

Bu eleştirel yaklaşımlara rağmen, şehir hastanelerinin sağlık tesislerinin daha modern bir yapıya kavuşmasında ve kalite odaklı sağlık hizmetlerinin sunulmasında önemli oranda katkı sağlayacağı yönünde olumlu bir beklenti söz konusudur. 2. TÜSAP Vizyon Toplantısında Türkiye'de sağlık sektörüne yön veren kamu ve özel sektörden 40 katılımcının \%62'si KÖi projelerinin hayata geçmesinin Türkiye'de sağlık hizmeti sunumuna olumlu katkı yapacağını, \%17'si ise, oldukça olumlu katkı yapacağını belirtmişlerdir. Ayrıca, şehir hastanelerinden beklenilen en büyük fayda olarak, katılımcıların $\% 29^{\prime}$ u hastaların tedavi kalitesinde artışı, 
\%18'i teknolojik modernleşmeyi ve \%50'si hasta konforunun artmasını belirtmişlerdir (TÜSAP, Sağlıkta Sürdürülebilirlik Vizyon Toplantısı, 17 Şubat 2017).

\section{Sonuç}

1980 'lerden itibaren liberal politikaların yaygınlık kazandığı ve özel sektör girişimcilerinin kamu hizmetlerinde daha çok rol aldığı bir süreç yaşanmaktadır. Dünya üzerinde yaygın bir uygulama alanı bulan bu paradigma değişimi, bir çok sektörde kamu tesislerinin ve hizmetlerinin özelleştirilmesi veya faklı modellerle KÖi uygulamaları şeklinde kendisini göstermektedir. Sağlık sektörü, bu değişim ve dönüşüm sürecinden en çok etkilenen sektörlerden biri olmuştur. Bu sektörde bir yandan özel sektör girişimcilerinin tüm sağlık hizmetlerini yürüttüğü uygulamalara gidilmekte bir yandan sağlık tesislerinin alt yapısını oluşturmak, sağlık hizmeti sunmak, ilaç geliştirmek, ilaçların dağıtımını yapmak ve salgın hastalıkların kontrolünü sağlamak gibi amaçlarla KÖi uygulamalarına gidildiği görülmektedir.

Türkiye'de 2003 yılından itibaren sağlık sektöründe çalışan personel yapısı, sağlık hizmeti sunulan fiziki mekânlar, teknolojinin daha yoğun kullanımı, hizmetin sunuluş şekli gibi boyutları ile sağılı hizmetlerinin sunumunda nitelik ve nicelik olarak çağdaş standartlara ulaşılması amacına yönelik bir değişim ve dönüşüm süreci başlatılmıştır. Bu sürecin önemli bir unsuru sağlık hizmetlerinde uygulanan KÖi modellerinden olan ve Birleşik Krallık kökenli "altyapı temelli model" örnek alınarak hayata geçirilen şehir hastaneleridir. Özel sektör girişimcisi ile kamu idaresi arasında imzalanan bir sözleşme çerçevesinde sağlık tesislerinin planlanması, finansmanı, inşası, işletilmesi, bakım ve onarımı ile destek hizmetlerinin sunulması iş ve işlemlerinin özel sektör girişimcisine bırakıldığı bu modelde asıl hizmet konumunda olan sağlık hizmetinin sunulması kamu personellerince gerçekleştirilmektedir.

2005 yılında şehir hastanelerinin yapımında benimsenen YKD modelinin mevzuat altyapısı oluşturulmuş ve 2017 yılında Yozgat Şehir Hastanesi'nin hizmete girmesiyle fiilen uygulanmaya başlanmıştır. 2018 sonu itibariyle Türkiye'de 8 şehir hastanesi işletme dönemine başlamış geri kalan 13 şehir hastanesinin ise sözleşmesi imzalanmış ve farklı aşamalarda inşa süreci devam etmektedir. Hizmete alınmış şehir hastanelerindeki uygulamalar, yapım süreci devam eden hastanelerin de hizmete alınmasıyla yaklaşık 30 bin yatak kapasitesine toplamda ise, 50 bin yatak kapasitesine ulaşacak şehir hastanelerinin sağlık hizmetlerinin değişimi ve dönüşümüne önemli oranda katkı sağlayacağını göstermektedir.

Hizmete alınan şehir hastaneleri üzerinde yapılan bilimsel araştırmalar bu değişim ve dönüşümün çok boyutlu bir şekilde hissedilmekte olduğunu ortaya koymaktadır. Bu hastanelerden hizmet alan hastalar üzerinde yapılan araştırmalarda hasta memnuniyetinin oldukça yüksek olduğu görülmektedir. Ayrıca, bu hastanelerin Türkiye'de sağlık tesislerinin fiziksel kapasitenin arttırılması, sağlık hizmetleri finansmanının bütçe üzerinde oluşturduğu baskının uzun vadelere yayılması, özel sektörün tecrübesinden ve yönetim uygulamalarından yararlanılması ve sağlık hizmetlerinde daha yoğun bir teknoloji kullanımı ile kalite standartlarının yükseltilmesine olumlu katkılar sunduğu söylenmelidir. Bazı eleştirel yaklaşımlara rağmen, şehir hastanelerinin Türkiye'de sağlık hizmetlerine katkıları inşa süreci devam eden hastanelerin hizmete alınmasıyla daha açık bir şekilde görülebilecektir. 


\section{Kaynakça}

Abuzaineh, N.; Brashers, E.; Foong, S.; Feachem, R.; Da Rita, P. (2018), “PPPs in healthcare: Models, lessons and trends for the future. Healthcare public private partnership series, No. 4. San Francisco: The Global Health Group, Institute for Global Health Sciences, University of California, San Francisco and PwC. Produced in the United States of America", https://globalhealthsciences.ucsf.edu/sites/ globalhealthsciences.ucsf.edu/files/pub/ppp-report-series-business-model.pdf,(Erişim: 26.4.2018).

Acerete, Basilio; Stafford, Anne; Stapleton, Pamela (2011), "Spanish healthcare public private partnerships: The 'Alzira model, Critical Perspectives on Accounting", Critical Perspectives on Accounting, Vol.22: 533-549.

ADN PPP Sağlık Yatırımları AŞ. (2014), “Adana Entegre Sağlık Kampüsü Projesi Çevresel ve Sosyal Etki Değerlendirmesi Teknik Olmayan Özet”, http://www.pppadanahastanesi.com/ tr/19536/Cevre-ve-Sosyal-Etki Değerlendirmesi, (Erişim: 28.09.2014).

Ankara Etlik Hastane Sağlık Hizmetleri İşletme Yatırım A.Ş, (2014), “Ankara Etlik Entegre Sağlık Kampüsü Projesi, Çevresel ve Sosyal Etki Değerlendirmesi (CSED) Raporu", www.aeh.com.tr/assets/ pdf/Etlik_ ESKP_CSED.pdf, (Erişim: 20.12.208).

Atasever, Mehmet vd. (2018), Şehir Hastaneleri Araştırması, , Ankara, Sağlık Sen Yayınları-46.

Aycı, İlker (2015), "Kamu Özel Iş̧birliği (KÖi) Sağlık Zirvesi - PPP Health Summit Basın Bülteni” 28 Nisan 2015, http://www.invest.gov.tr/tr-TR/infocenter/pressrelease/Documents/28-04-2015-TYDTA-KOI-SAGLIKZIRVESI.pdf, (Erişim: 15.01.2016).

Aydın, Sabahattin (2015), “Entegre Sağlık Kampüsleri veya nam-ı diğer Şehir Hastaneleri”, Sağlık Düşüncesi ve Tıp Kültürü Dergisi, Mart-Nisan-Mayıs, 34, 12-19.

Barros, Pedro Pita; Giralt, Xavier Martinez (2009), "Contractual design and PPPs for hospitals:lessons for the Portuguese model", The European Journal of Health Economics, Vol. 10 Núm. 4, 437-453.

Biginas, Konstantinos; Sindakis, Stavros (2015), "Innovation through Public-Private Partnerships in the Greek Healthcare Sector: How is it achieved and what is the current situation in Greece?", The Innovation Journal: The Public Sector Innovation Journal, Volume 20(1), 2015, article 5, 1-11.

Constantinescu, Dan (2012) "Public-private partnership role in increasing the quality of the health insurance services" Theoretical and Applied Economics, Volume XIX, No. 10 (575), 31-45.

Çakır, Mehmet Kadir (2016) 6428 Sayılı Kanuna Göre Kamu Özel İsbirliği Kavramı ve Yeni Bir Model: Yap kirala Devret, Seçkin Yayınları, Ankara.

Çınar, Naif Fıratcan; Türkoğlu, Çağdaş, Sütünsatar, Alper (2017), “Kamu-Özel Ortaklığı/Iş̧birliği Modeli ve Sağlık Hizmetlerinin Sunumunda Hizmet Memnuniyetinin Ölçülmesi: Entegre Sağlık Kampüsleri (Şehir Hastaneleri) için Bir Araştırma”, Süleyman Demirel Üniversitesi Sosyal Bilimler Enstitüsü Dergisi Yıl: 2017/4, Sayı:29, 215-232.

European Commission (2013), "Health and Economics Analysis for an evaluation of the Public Private Partnerships in health care delivery across EU", http://ec.europa.eu/health/expert_panel/ documents/publications/docs/ppp_finalreport_en.pdf, (Erişim: 14.05.2017).

Gibbs, Tony (2008), “An Assessment of Turn-key Contracts for the Realisation of Capital Works Projects Principally for Public Sector Healthcare Facilities, The United States Agency for International Development"http://www.disaster-info.net/safehospitals_refdocs/documents/english/windhaza rdmaps/WindHazards_Turn-key.pdf, (Erişim: 19.01.2016).

Gökkaya, Durmuş; İzgüden, Dilruba; Erdem, Ramazan (2018), “Şehir Hastanesinde Hasta Memnuniyeti Araştırması: Isparta İli Örneği”, Süleyman Demirel Üniversitesi Vizyoner Dergisi, Yıl: 2018, Cilt: 9, Sayı: 20, 136-148.

Grimsey, Darrin; Lewis, Mervyn K. (2004), Public Private Partnership The Worldwide Revulation in Infrastructure Provision and Project Finance, Edward Elgar Publishing Lim., Cheltenham U.K.

Health Research Institute (2010), "Build and Beyond: the (r)evolution of healthcare PPPs", https://www. wko.at/Content.Node/PlattformGesundheitswirtschaft/StudienPublikationen/Studien/build-and-beyondrevolution-of-healthcare-ppps.pdf, (Erişim: 02.11.2015).

Hellowell, Mark (2012), "The role of public-private partnerships in health systems is getting stronger", http://www.sps.ed.ac.uk/_data/assets/pdf_file/0008/96245/2012_PPP_getting_stronger_Commonwealt h_Health_Partnerships_2012.pdf, (Erişim: 27.04.2016).

Hodge, Graeme; Greve, Carsten (2007), “Public-Private Partnerships: An International Performance Review”. Public Administration Review. 67, 67(3). 545-558

International Monetary Found (2004), "Public-Private Partnerships, Fiscal Affairs Department", https://www.imf.org/external/np/fad/2004/pifp/eng/031204.pdf, (Erişim: 23.02.2017). 
Joyner, Kate (2007), “Dynamics Evolution in Public-Private Partnerships, The Role of Key Actors in Managing Multiple Stakeholders". Managerial Law, Volume 49, No. 5/6, 205-217.

Kantarcı, Fuat (2016), "Akıllı hastaneler geliyor", http://www.trthaber.com/haber/saglik/akilli-hastaneler-geliyor246089.html, (Erişim: 21.04.2016).

Karahanoğulları, Onur (2011), "Kamu Hizmetleri Piyasa İlişkisinde Dördüncü Tip: Eksik İmtiyaz (Kamu-Özel Ortaklı̆̆ı”, Ankara Üniversitesi SBF Dergisi, Cilt 66, No. 3, Ankara, 2011, 177-215.

Kılavuz, Emine (2010), "Sağlık Harcamalarındaki Artış ve Temel Bakım Hizmetleri”, Sosyal Bilimler Enstitüsü Dergisi, Sayı: 29 Yıl: 2010/2, 173-192.

Mckee, Martin; Edwards, Nigel; Atun, Rifat (2006), "Public-private partnerships for hospitals" Bulletin of the World Health Organization, 84, 890-896.

Mendelson, D. N.; Schwartz, W. B. (1993) "The Effects of Aging and Population Growth on Health Care Costs", Health Affairs, 12(1): 119-125.

Müezzinoğlu, Mehmet (2015), "Kamu Özel İşbirliği (KÖi) Sağlık Zirvesi - PPP Health Summit Basın Bülteni”, http://www.invest.gov.tr/tr-TR/infocenter/pressrelease/Documents/28-04-2015-TYDTA-KOI-SAGLIKZIRVESI.pdf, (Erişim: 15.01.2018).

Nikolic, Irina A.; Maikisch,Harald (2006), "Public-Private Partnerships and Collaboration in the Health Sector An Overview with Case Studies from Recent European Experience", http://documents.worldbank. org/curated/en/909681468139198131/Public-private-partnerships-and-collaboration-in-the-health-sectoran-overview-with-case-studies-from-recent-European-experience, (Erişim: 13.02.2018).

OECD, (2015), "Focus on Healt Spending, OECD Health Statistics 2015", http://www.oecd.org/health/ healthsystems/Focus-Health-Spending-2015.pdf, (Erişim: 16.01.2016).

Oxfam Brienfing Note, (2014), "A Dangerous Diversion, Consumers Protection Association”, www.oxfam.org, (Erişim: 05.04.2016).

Sağlık Bakanlığı (2003), "Sağlıkta Dönüşüm”, https://www.saglik.gov.tr/TR,11415/saglikta-donusum-programi, (Erişim: 20.10.2018).

Sağlık Bakanlığı (2010), Sağlıkta Dönüşüm Programı, Sağlık Bakanlığı Yayınları, Ankara.

Sağlık Bakanlığı, (2018), "Sağlık İstatistikleri Yıllığı 2017”, https://sbsgm.saglik.gov.tr/ TR,49093/saglik-istatistikleriyilligi-2017-haber-bulteni.html, (Erişim: 05.01.2019).

Sağlık Bakanlığı (2019), "Sözleşmesi İmzalanan Şehir Hastaneleri”, https://sygm.saglik.gov.tr/ TR,33960/sehirhastaneleri.html, (Erişim: 05.01.2019).

Sağlık Bakanlığınca Kamu Özel İşbirliği Modeli ile Tesis Yaptırılması, Yenilenmesi ve Hizmet Alınması İle Bazı Kanun Hükmünde Kararnamelerde Değişiklik Yapılması Hakkında Kanununun Genel Gerekçesi, 2014

Sayıştay Başkanlığı (2018), "Türkiye Kamu Hastaneleri Kurumu 2017 Yılı Sayıştay Denetim Raporu", https://www.sayistay.gov.tr/tr/Upload/62643830/files/raporlar, (Erişim: 10.01.2019).

Shukla, Nirali; Panchal, Riki; Shah, Neel (2014), “Built-Own-Lease-Transfer (BOLT): A Public Private Partnership Model that Bridges Gap of Infrastructure in Urban Areas, International Journal of Civil Engineering Research, ISSN 2278-3652 Volume 5, Number 2, 135-144.

T.C Başbakanlık Devlet Planlama Teşkilatı Müsteşarlığı (2009), “2009-2013 Stratejik Planı”, DPT Stratejik http://iklim.cob.gov.tr/iklim/Files/Stratejiler/2009_2013StratejikPlan.pdf, (12.02.2016).

T.C. Başbakanlık Kanunlar ve Kararlar Genel Müdürlüğü, (2012), 7.12.2012 tarih ve B.02.0KKG.0.10/101-663/5230 sayı.

The Global Health Group University of California (2010), "Public-Private Investment Partnerships for Health, An Atlas of Innovation", San Francisco, http://globalhealthsciences.ucsf.edu/sites/default/files/ content/ghg/hsippip-atlas.pdf, (Erişim: 20.04.2016).

TBMM Plan ve Bütçe Komisyonu Raporu, (2005), “Bursa Milletvekili M.Altan Karapaşaoğlu'nun; 3359 Sayılı Sağlık Hizmetleri Temel Kanununa Bir Ek Madde Eklenmesi Hakkında Kanun Teklifi ile Plan ve Bütçe Komisyonu Raporu)" (2/540).

TÜSAP (2017), “Sağlıkta Sürdürülebilirlik Vizyon Toplantısı”, 17 Şubat 2017, http://tusap.org/wpcontent/uploads/2017/10/TUSAP.pdf, (Erişim: 10.01.2019).

Yılmaz, Ferimah Yusufi; Karakaş, Derya Gültekin, (2011), “Devlet Kamu Üzerine Yeniden Düşünmek, Sağlıkta Kamu Özel Ortaklığı'nın Yapısal/Konjonktürel ve Türkiye'ye Özgü Nedenleri, Sağlık Alanında Kamu-Özel Ortaklığ Sempozyumu", Bursa, 6-7 Mayıs 2011. 
Eskişehir Osmangazi Üniversitesi iiBF Dergisi 